\title{
Influencing Factors of a Sustainable Vegetable Choice. The Romanian Consumers' Case
}

\author{
Georgiana-Raluca Ladaru ${ }^{1}$, Diana Maria Ilie ${ }^{2}$, Maria Claudia Diaconeasa ${ }^{1}$, \\ Ionut Laurentiu Petre ${ }^{3, *} \mathbb{0}$, Florian Marin ${ }^{1}$ and Valentin Lazar ${ }^{3}$ \\ 1 The Department of Agrifood and Environmental Economics, The Bucharest University of Economic Studies, \\ 010961 Bucharest, Romania; raluca.ladaru@eam.ase.ro (G.-R.L.); maria.diaconeasa@eam.ase.ro (M.C.D.); \\ florian.marin@eam.ase.ro (F.M.) \\ 2 The Agricultural Economics Office, The Research Institute for the Economy of Agriculture and \\ Rural Development, 011464 Bucharest, Romania; necula.diana@iceadr.ro \\ 3 Doctoral School of Economics II, The Bucharest University of Economic Studies, 010961 Bucharest, Romania; \\ valentin.lazar@ase.ro \\ * Correspondence: laurentiu.petre@eam.ase.ro; Tel.: +40-727-571-841
}

Received: 20 November 2020; Accepted: 27 November 2020; Published: 29 November 2020

\begin{abstract}
The behavior of vegetable consumption in the context of sustainable development has become a point of interest. Determining the barriers and the drivers for developing a sustainable consumption pattern, including food, should be a priority for every nation, as so to be able to design targeted food policies that would contribute to this development. Reducing the pressure on resources by diminishing meat consumption and increasing vegetable consumption is one of the global directions that should be followed. The situation of the current status of vegetable consumption in Romania is, therefore, important. Through an empirical quantitative analysis, the vegetable consumption pattern of Romanian consumers is presented. The results show that the respondents lack proper environmental education and concern, but unconsciously are aware of sustainability criteria such as choosing local and seasonal vegetables, choosing according to the freshness of the vegetables, and wasting little of these purchases. The main barriers determined in developing more sustainable vegetable choices in the case of Romanian consumers are income and time availability restrictions. It is also important to have the ability to identify the local, seasonal, and organic vegetables through specific labels, and to provide the local producers with the ability to sell their products in supermarkets, at fair prices. These would be the main drivers for developing a sustainable vegetable choice. Adding to that, an awareness campaign at the national level regarding the importance of individual choice would contribute to educating towards a sustainable purchasing pattern.
\end{abstract}

Keywords: sustainable diet; vegetable diet; sustainable vegetables; vegetable consumption pattern

\section{Introduction}

Eating vegetables is a multifaced issue since childhood and, for some of us, until the end of our lives. The importance of vegetables in nutrition is acknowledged in various studies [1,2], the consumption of this food category being widely promoted through public policies [1,3], food education [4-7], and, in a newer context, as taking action towards sustainable development [8,9]. However, people still tend to eat more animal proteins instead of vegetable proteins.

Starting from picky children [10] who have a hard time adjusting to vegetables in their diets, to adults who developed specific unhealthy eating patterns that may be considered as addictions [11], people seem to prefer meat and saturated fats to vegetables. Furthermore, other authors consider that eating animal protein, especially meat, is a form of showing a recently obtained wealth or status [12], 
so significant regional disparities may be observed: North American and Western European populations have a higher number of obese people [4], while the developing populations have healthier people from this point of view, but follow a rising tend regarding meat-eating [13]. More, the most recent report from the United Nations [14], mentions the fact that only upper-middle-income countries have enough fruits and vegetables available to consumers so that the recommendations of $400 \mathrm{~g}$ per day may be followed, at the global level, so the low-income-countries rely on cereals to ensure the food security of the population, the dietary pattern being transferred to a secondary plan. Nevertheless, important steps towards changing the dietary patterns are made through globally extended food policies and dietary guidelines [15-20], research-based recommendations [21,22], and dietary education [7,23,24].

Considering the previous studies on the topic of sustainable diets, their definition includes references to nutritional aspects [3,11,25], social aspects [26,27], economic aspects [28,29] and not last, environmental aspects, such as: type of production, inputs, water usage, provenance, and even transportation and storage of the products [29,30]. Yet, providing a clear definition for a sustainable diet is still not possible [31], since the four aspects are not self-defined, but they are interrelated [32,33].

Romania is one of the current 27 Member States of the European Union, part of the Eastern European block. The country is working on solving some critical problems such as social polarization [34], a rate of $32.5 \%$ of the people being exposed to the risk of extreme poverty [35] and an average Gross Domestic Product equal to one-fifth of the EU average [36], hence the purpose of this study is to determine the possibility of the Romanian population to meet the dietary recommendations regarding the vegetable consumption, and if not, what are the main barriers perceived by the Romanian consumers. Some studies provide that Romania's consumption pattern is heavily based on traditional meat dishes and has a low presence of environmental concern [37], but that the young population prefers the organic and local grown food [38]. Moreover, the income serves as the prime factor in the choice of food for Romanians [39]. Considering the current stage of economic development in Romania, the above-mentioned barriers in consuming vegetables and the global directives towards shifting the consumption pattern towards a significantly higher plant-based one, the objectives of the current studies may be stated as follows:

(1) Determining the differences in vegetable consumption based on income, gender, and age for Romanian consumers;

(2) Determining the purchasing preferences for the Romanian vegetable consumers (frequency, source, choice criteria) considering income and age segmentation;

(3) Determining the appreciation of vegetable availability for Romanian consumers based on income differences;

(4) Determining the vegetable waste level for Romanian consumers and availability to pay more for vegetables based on income segmentation.

Nevertheless, the analysis was conducted during a time of relative world peace when people can spare their time to think and decide for their future. As history proves, periods of peace may also be recognized as periods of great development in human lives, a progress that has helped us to live longer and healthier lives. On the other hand, the periods of crisis, such as wars or plagues, have hindered the development for a better life. The COVID-19 pandemic is, very much, a time of world crisis, when decisions regarding sustainable development have taken a step back in front of the urgent issues of health and economic security. Adding on that, the rapid trace of events has pushed every individual to impulsive consumption pattern changes, relating also to food. Since the spring of 2020, around the world, severe shortages of non-perishable foods have been encountered, followed by an increase in food waste. Other significant behavior changes for food consumption were generated by the restaurants closing, the increased request for food delivery, as well as a rediscovery of home cooking. All of these, along with a constant fear of going to the market and of buying fresh vegetables, generated by contradictory health recommendations, led to the insolvency of producers who were dependent on their daily sales to survive. 
This study is of further use to researchers as a point of comparison and development of other studies regarding sustainable vegetable consumption, as well as to policymakers, who may consider its results in building further health and food policies tailored to this country's specifics and to its consumers' expectations. The authors are aware of the fact that this topic is not unique. Yet, its perspective contributes significantly to the development of the research area.

\section{Theoretical Background}

Ever since the appearance of the Brundtland report (1987), the topic of sustainable development has gained awareness and has become a priority for the survival of the world. Yet, sustainability is not as new as it seems. The idea of it has been used even in ancient societies [40] where the collective wellbeing was cherished. Sanitation and sewage systems, common bathrooms, and irrigation systems were sustainably designed by following the natural laws of physics and without harming the natural environment [41]. Unfortunately, the ancient knowledge of environmental harmony [42,43] was replaced by economic principles of productivity [44]. This common use of natural goods has been later described as "the tragedy of the commons" [45,46] because of the human incapacity of sharing in the long term, hence the overuse of the natural resources $[8,47,48]$, proceeded by an inequitable fight for the highest share $[49,50]$ between the rich and the poor populations [51].

Considering that food comes from the use of natural, and often common, resources such as water and soil, and having food is considered a right in the modern world $[52,53]$, the sustainable production [54-56] and consumption [57,58] of food have become pressing problems in order to reach sustainable development. As with any other problem that affects the future of humanity, the change of patterns for both production and consumption of food have strong policy implications, either at the global level, with more general recommendations such as the Sustainable Development Goals [14] or at the regional level, with more applied actions [59].

Public policies that aim towards obtaining sustainable food systems [60] are theoretically designed for all stakeholders involved, considering their possible level of contribution [59]. Therefore, there are specific policies who address food production and distribution so to determine these sectors to become more sustainable [61] through alternative production systems [56], new inputs [62], using biofuels [63], waste reduction through the circular economy [64] or reducing the resource consumption [65]. Other policies aim at the individual consumer, a fact that is justified considering the need to feed a growing number of people [66]. Some of the recommendations for individual consumers include choosing organically produced food [67], reducing food waste [57], or choosing locally produced food [68], as well as reducing meat consumption and increasing vegetable consumption [69,70].

The consumer-directed policies provide a mixed approach for convincing the individuals to pursue a sustainable food choice, respectively they combine the health aspect, the environmental aspect, and the ethical aspect of the simple choice of food [70-72]. Therefore, one may say they are using both emotions [73,74] and education [75-77] to forge a new food consumption pattern.

In the same direction, public health policies are aiming at promoting vegetable consumption and reducing meat and saturated fats consumption, hence reducing the number of people with diseases associated with a high animal protein-based diet [1,15].

Yet, there are factors more powerful than policies that influence the food choice of people in different regions. Some of these identified factors are biological (hunger level, taste) [1,78,79], physical (access to food, available time or even cooking skills) [78], economic (income, availability of food) [79], social (family, education, culture) [6,79], psychological (stress level, mood, guilt) [74-76] and attitudes, beliefs or knowledge related to food [80,81]. Some authors recommend differentiating the public recommendations towards sustainable diets by age groups since the young adults are more likely to pursue such recommendations $[38,82]$. While [83] see an opportunity in promoting plant-based diets to the elderly, since they are inclined to accept them rather than other food consumption alternatives. The hypothesis that underpins this study is based on previous research on the topic and, the first one is: 
Hypothesis 1. Young adults are more likely to choose a more vegetable-based diet based on environmental considerations than elderly people.

Several authors promote a direct attitude towards the need for a shift in the global dietary patterns $[5,8,21,22,84]$, stating the obvious, namely: the low intake of fruits and vegetables and the high intake of meat can lead to chronic diseases. Additionally, through their studies, they propose alternatives to the current consumption patterns. For example, sustainable diets [3], change of language on vegetable product labels into a more stimulating one [85], plant-based and oat-based protein consumption [22], or food education for children and parents [6,86], therefore aiming at the health aspect of a sustainable food choice [87].

Other authors emphasize the need to embrace a sustainable consumption pattern, food consumption included, due to the high level of Greenhouse Gas Emissions generated by the current household consumption, so the environmental aspect, [88-91], more than $70 \%$ of the emissions coming from households. Regarding the food consumption segment, the exposed solutions circle the same ideas, e.g., less carbon-intensive diets [89]; less meat-based diets [89,91]; more plant-based or insect-based diets [22,91]; choosing seasonal, locally, or organically grown products [91]. Some authors debate that Japanese consumers are more interested in the sustainable aspects of vegetables (organically grown, the origin of cultivation) when they are out of season, rather than when in-season [92]. Additionally, some authors imply that high incomes are needed to pursue a healthier consumption pattern $[28,39]$. Considering this, the second and third hypotheses are:

Hypothesis 2. Romanian consumers with middle and high incomes purchase vegetables with a high frequency no matter the season, while low-income consumers buy vegetables that are in-season more frequently.

Hypothesis 3. Young consumers are likely to pay more for ecologically produced vegetables.

The choice of a more plant-based diet contributes not only to lowering the risk of chronic disease but are also recommended as environmentally sustainable, as some studies $[25,93]$ reveal. It appears that some regions of the world are, by tradition, more sustainable in food choice, hence they have more vegetable prone diets than others. The Mediterranean and Nordic diets are seen as sustainable due to the importance given to vegetables [25]. Other studies debate that vegetables with genetic origins in specific regions, as is the purple carrot in Spain, are more environmentally sustainable for cultivation in those regions, and by choosing them, the people inhabiting the same regions are healthier [94]. Yet, as Perez-Caselles et al. [28] claim, these traditional crops are less economically productive, therefore undesirable for large farms, but suitable for small farms that address the needs of niche consumers. Yet, some authors consider that there is much more pressure on farmers to pursue sustainable agriculture than it is on consumers to choose sustainably produced vegetables [95]. Wood et al. [90] claim that a shift towards a vegetable plant diet combined with the reduction of food waste would have the most significant impact on reducing the carbon footprint of the American diet. Hence, the fourth and fifth hypotheses are:

Hypothesis 4. Young Romanian consumers are more likely to purchase vegetables from local producers, while older consumers prefer the supermarkets for purchasing vegetables.

Hypothesis 5. People with higher incomes are more likely to waste vegetables than people with lower incomes.

Some regional studies identified a series of common barriers for vegetable consumption, such as: the general dislike of taste $[10,84]$, the considerable lack of time needed for shipping or cooking $[10,21]$, picky children [10], high costs of purchasing sustainably produced vegetables [10,21], limited availability of fresh vegetables and high availability of other foods [21,84] for the healthy food categories, vegetables included, as one of the main barriers in front of their availability, an idea also supported by 
research [39]. Pocol et al. [96] claim that young adults from Romania, Bulgaria, and Moldova need dietary education for developing a long-term sustainable food pattern and that gender is an important factor in choosing a sustainable diet. Moreover, Piester et al. [97] claim that under the influence of sustainability-related information, women are more likely to make a sustainable vegetable choice than men. Therefore, the sixth and seventh hypothesis are:

Hypothesis 6. Price is the most important factor in the decision to purchase vegetables for people with lower incomes, while quality is the most important factor for people with medium and higher incomes.

Hypothesis 7. Women consume vegetables more often than men; hence they have a more sustainable diet.

As proof of common action towards promoting vegetable consumption, in the context of healthy eating, several countries in the world have developed dietary guidelines as part of their national health policies. Even so, reported to the approximate total number of countries in the world (195), not even half of the countries have such dedicated guiding. According to FAO [98], the number of countries with dietary guidance, developed by the dedicated national institutions until 2018, per region is as follows in Table 1.

Table 1. Number of countries with dietary guidelines per world region.

\begin{tabular}{cc}
\hline World Region & Number of Countries with Available Dietary Guidelines by 2018 \\
\hline Africa & 7 \\
Asia and Pacific & 18 \\
Europe & More than 30 \\
Latin America and the Caribbean & 25 \\
Near East & 4 \\
North America (Canada and the USA) & 2 \\
\hline
\end{tabular}

Source: FAO, 2020.

The regular vegetable intake recommendations are present in all countries' dietary guidelines since they are part of the World Health Organization. Yet, there are some sensitive differences between the formulations and visual aid used in the guidelines. In Table 2 a series of examples from different national dietary guidelines are presented.

Since the recommendations of eating vegetables are currently made with a global reference, because there are specially designed documents referring to large areas, the general idea that may be extracted is that of an unbalanced dietary pattern that does not support the development of a healthy life. In this context, the UN dedicates the second Sustainable Development Goal directly to the area of food, including here the availability of food, dietary patterns, and healthy development [14]. As the level of food insecurity is higher, the consumption of healthy food, where vegetables are included, is significantly lower, as such the relation is one of direct influence [14].

The common recommendation for the European area includes aspects that transcend the health rationale. The "fresh" and "local" adjectives describing the fruits and vegetables are sustainability aspects [22,28,82,91] elegantly inserted in the European consumers' vocabulary.

Even if it is hard to provide a commonly agreed definition [31], sustainable food choice refers, in short, to choosing the product that best fits a consumers' needs, based on available regional or local resources and liking, taking also into consideration the social and environmental responsibilities and characteristics of the community[74,81,91,99]. 
Table 2. References to vegetable intake in worldwide dietary guidelines.

\begin{tabular}{|c|c|c|c|c|}
\hline Issuer & $\begin{array}{l}\text { Country/Region } \\
\text { of Reference }\end{array}$ & $\begin{array}{l}\text { Year of } \\
\text { Issue }\end{array}$ & Reference & Observations \\
\hline USDA & USA & 2018 & $\begin{array}{l}\text { "A healthy eating pattern includes: } \\
\text { a variety of vegetables from all of } \\
\text { the subgroups-dark green, red } \\
\text { and orange, legumes (beans and } \\
\text { peas), starchy and other" }\end{array}$ & $\begin{array}{l}\text { It is the first recommendation } \\
\text { from the guideline list. It comes } \\
\text { with significant visual aid } \\
\text { (pictures, graphs) expressing the } \\
\text { proportions of different nutrients } \\
\text { in a daily portion of food. }\end{array}$ \\
\hline $\begin{array}{l}\text { Australian } \\
\text { Government }\end{array}$ & Australia & 2013 & $\begin{array}{l}\text { "Enjoy [ ... ] plenty of vegetables } \\
\text { of different types and colors, and } \\
\text { legumes/ beans" }\end{array}$ & $\begin{array}{l}\text { It is the first recommendation } \\
\text { from the list. It comes with } \\
\text { significant visual aid. }\end{array}$ \\
\hline $\begin{array}{l}\text { National } \\
\text { Institute of } \\
\text { Nutrition }\end{array}$ & India & 2011 & $\begin{array}{l}\text { "Eat plenty of vegetables and } \\
\text { fruits" }\end{array}$ & $\begin{array}{l}\text { The recommendation comes after } \\
\text { several mentions related to food } \\
\text { security and safety, such as clean } \\
\text { food and the need for } \\
\text { breastfeeding in infants. Available } \\
\text { visual aid (the pictures are less } \\
\text { expressive than the USDA and } \\
\text { Australian ones). }\end{array}$ \\
\hline WHO & $\begin{array}{l}\text { Asian and } \\
\text { Pacific regions }\end{array}$ & 1997 & $\begin{array}{l}\text { "Eat plenty of vegetables and fruit } \\
\text { regularly" }\end{array}$ & $\begin{array}{l}\text { The document referred to the } \\
\text { entire region. Some of the } \\
\text { countries developed their own } \\
\text { guideline since then. Little visual } \\
\text { aid (simple images with } \\
\text { little impact). }\end{array}$ \\
\hline WHO & $\begin{array}{l}\text { European } \\
\text { Union, Iceland, } \\
\text { Norway, } \\
\text { Switzerland, } \\
\text { and the UK }\end{array}$ & 2003 & $\begin{array}{l}\text { "Daily intake of fresh and local } \\
\text { vegetables and fruit" }\end{array}$ & $\begin{array}{l}\text { Some refer their recommendations } \\
\text { to the vegetable and fruit category, } \\
\text { while others differ among the two. } \\
\text { Visual aid is adapted for each } \\
\text { country with a dietary guide. }\end{array}$ \\
\hline $\begin{array}{l}\text { Canadian } \\
\text { Government }\end{array}$ & Canada & 2019 & $\begin{array}{l}\text { "Vegetables, fruit, whole grains, } \\
\text { and protein foods should be } \\
\text { consumed regularly. Among } \\
\text { protein foods, consume } \\
\text { plant-based more often." }\end{array}$ & $\begin{array}{l}\text { This is the first recommendation } \\
\text { on the list. Significant visual aid. } \\
\text { Constant correlation to the } \\
\text { environmental importance of } \\
\text { food choice. }\end{array}$ \\
\hline
\end{tabular}

Source: authors' own abstracting after USDA [15], WHO [16], Australian Government [17], WHO [18], Indian National

Institute of Nutrition [19] and Canadian Government [20].

\section{Materials and Methods}

For conducting this research, the authors considered an empirical quantitative investigation [100] for collecting data directly from the vegetable consumers in Romania, through the technique of structured self-administrated questionnaires [101]. The designed questionnaire was first face-to-face pilot tested on 15 persons for ensuring the validity of the research [102].

The sampling method considered was the convenience sampling, through the "snowball" method [103] and the sampling size was calculated using the Taro Yamane method [104-106], by the following equation:

$$
n=\frac{N}{\left(1+N \times e^{2}\right)^{\prime}},
$$

where " $\mathrm{N}$ " is the total considered population, in this case, $17,592,625$ persons with ages above 15 years old, since younger consumers do not have the power of decision when buying food products, even if they have an influence on the family decision [86,107]. " $\mathrm{e}$ " is the accepted error, in this case, $5 \%$, and " $\mathrm{n}$ " being the resulted sampling size. For this study, the calculated sampling size is equal to 400 persons. The total number of answers gathered and validated for this research is 403 , respecting the sampling size, but not the gender and the age structure of the population.

The independent variables considered for this research are gender, age, and income, while the dependent variables are the consumer preferences for vegetable consumption that may be related to sustainable or unsustainable consumption. 
Descriptive analysis through the use of descriptive statistics $[108,109]$ will be further used in order to confirm or to infirm the previously mentioned hypothesis. The software used for data interpretation is SPSS 20 [101,110].

The structure of the consumer sample based on age, gender and income may be observed in Table 3.

Table 3. Sample structure based on age, gender, and income level.

\begin{tabular}{|c|c|c|c|c|c|c|c|c|c|c|c|c|c|}
\hline & & $\begin{array}{l}15-19 \\
\text { y.o }\end{array}$ & $\begin{array}{l}20-24 \\
\text { y.o }\end{array}$ & $\begin{array}{l}25-29 \\
\text { y.o }\end{array}$ & $\begin{array}{l}30-34 \\
\text { y.o }\end{array}$ & $\begin{array}{l}\text { 35-39 } \\
\text { y.o }\end{array}$ & $\begin{array}{l}40-44 \\
\text { y.o }\end{array}$ & $\begin{array}{l}45-49 \\
\text { y.o }\end{array}$ & $\begin{array}{l}50-54 \\
\text { y.o }\end{array}$ & $\begin{array}{l}54-59 \\
\text { y.o }\end{array}$ & $\begin{array}{l}60-64 \\
\text { y.o }\end{array}$ & $\begin{array}{l}>70 \\
\text { y.o }\end{array}$ & $\begin{array}{c}\text { Total in Age } \\
\text { Group }\end{array}$ \\
\hline \multirow{2}{*}{$\begin{array}{c}\text { Gender } \\
\text { distribution }\end{array}$} & $\mathrm{F}^{*}$ & 0.0 & 42.8 & 7.6 & 4.7 & 4.7 & 17.3 & 13.3 & 7.9 & 1.1 & 0.7 & 0.0 & 68.98 \\
\hline & M & 0.8 & 41.6 & 8.0 & 4.8 & 4.8 & 9.6 & 15.2 & 10.4 & 0.8 & 3.2 & 0.8 & 31.02 \\
\hline \multirow{6}{*}{$\begin{array}{c}\text { Income } \\
\text { distribution }\end{array}$} & $<1000$ lei & 2.9 & 64.7 & 5.9 & 0.0 & 5.9 & 5.9 & 8.8 & 5.9 & 0.0 & 0.0 & 0.0 & \\
\hline & 1001-2000 lei & 0.0 & 40.7 & 1.7 & 0.0 & 1.7 & 16.9 & 22.0 & 13.6 & 0.0 & 3.4 & 0.0 & \\
\hline & 2001-3000 lei & 0.0 & 57.7 & 8.3 & 1.9 & 1.9 & 12.8 & 10.3 & 4.5 & 1.3 & 1.3 & 0.0 & \\
\hline & 5001-6000 lei & 0.0 & 10.5 & 21.1 & 10.5 & 15.8 & 10.5 & 21.1 & 10.5 & 0.0 & 0.0 & 0.0 & \\
\hline & $>6000$ lei & 0.0 & 13.5 & 0.0 & 16.2 & 10.8 & 29.7 & 16.2 & 8.1 & 0.0 & 2.7 & 2.7 & \\
\hline & $\begin{array}{l}\text { Total in age } \\
\text { group (\%) }\end{array}$ & 0.2 & 42.4 & 7.7 & 4.7 & 4.7 & 14.9 & 13.9 & 8.7 & 1.0 & 1.5 & 0.2 & 100.00 \\
\hline
\end{tabular}

Source: authors' calculations; ${ }^{*}$ F: females, M: Males, lei: RON (Romanian currency), y.o: years old.

The structure of the sample is formed by significantly more women than men, with more than $37 \%$. Considering the National Statistics Institute of Romania [109], the number of women in the population is higher than men, with approximately 4 million more women. The distribution of the sample considering the age variable shows that the youth category is more present among respondents to this study, $55.1 \%$ are people between 15 and 34 years old and $44.9 \%$ are people between 35 and above 70 years old. Within the age categories, the lower incomes are distributed to the younger respondents. The 20 to 24 years old category has the most recordings for incomes below 1000 lei $(64.7 \%)$, between 1000 and 2000 lei (40.7\%), between 2001 and 3000 lei (57.7\%), and within the 3001-4000 lei category (31.9\%). For the 4001-5000 lei category, the most present age category is the 40-44 years old, for the 5001-6000 lei category there are two representative age categories, the 25-29 years old and $45-49$ years old $(21.1 \%)$. The highest category of income has most respondents in the 40-44 years old category, along with $30-34$ and $45-49$ years old (16.2\%).

Considering the previously mentioned sustainability recommendations for individual consumers, the questionnaire was built to gather responses to these recommendations without inserting any direct mentions of sustainability in the questions, therefore reducing possible biased answers.

\section{Results and Discussions}

The respondents that are vegetable consumers, based on their respective age categories, gender, and their distribution by the relative quantity of vegetables consumed regularly (by their own appreciation), may be observed in the Table 4.

It is important to notice that there are only $1.2 \%$ of the respondents who declare they do not eat any vegetables, all of them being in the 20-24 years old category. Very low consumption of vegetables is reported by $3.5 \%$ of the respondents, the most representative age category being the 40-44 years old. The low and very high categories record the same moderate percentage of $19.6 \%$ in total respondents. The 45-49 age category has the highest number of respondents with low consumption of vegetables, while the most representative category for the very high consumption of vegetables is the 30-34 years old. The category registering a high consumption of vegetables is the most representative for all age categories. The young categories, below 35 years old, record lower proportions of high vegetable consumption than the older categories.

Considering gender differences, female respondents register higher percentages in the high and very high categories, while male respondents register higher percentages in the lower consumption categories. Therefore, at a first glance, the final hypothesis (H7) may be confirmed because female 
respondents have a higher consumption of vegetables than male respondents, without considering the type of production, seasonality, or regionality.

Table 4. Self appreciated consumption of vegetables by gender and age categories.

\begin{tabular}{cccccc}
\hline & No Vegetables (\%) & Very Low (\%) & Low (\%) & High (\%) & Very High (\%) \\
\hline females & 0.4 & 2.9 & 17.3 & 56.8 & 22.7 \\
males & 3.2 & 4.8 & 24.8 & 54.4 & 12.8 \\
15-19 y.o * & 0.0 & 0.0 & 0.0 & 100.0 & 0.0 \\
20-24 y.o & 2.9 & 4.7 & 22.2 & 50.3 & 19.9 \\
25-29 y.o & 0.0 & 0.0 & 19.4 & 67.7 & 12.9 \\
30-34 y.o & 0.0 & 0.0 & 21.1 & 47.4 & 31.6 \\
35-39 y.o & 0.0 & 5.3 & 10.5 & 63.2 & 21.1 \\
40-44 y.o & 0.0 & 6.7 & 15.0 & 58.3 & 20.0 \\
45-49 y.o & 0.0 & 0.0 & 23.2 & 60.7 & 16.1 \\
50-54 y.o & 0.0 & 2.9 & 17.1 & 57.1 & 22.9 \\
54-59 y.o & 0.0 & 0.0 & 0.0 & 75.0 & 25.0 \\
60-64 y.o & 0.0 & 0.0 & 0.0 & 83.3 & 16.7 \\
>70 y.o & 0.0 & 0.0 & 100.0 & 0.0 & 0.0 \\
Total & 1.2 & 3.5 & 19.6 & 56.1 & 19.6 \\
\hline
\end{tabular}

Source: authors' calculations; ${ }^{*}$ y.o: years old.

When speaking about the distribution of vegetable consumption by levels of income, an interesting situation appears. The high and very high consumption of vegetables has the most answers in all income categories. Yet, for the high consumption category, a significantly decreasing trend of consumption is registered along with the increase in income. While for the very high consumption category the same phenomenon is registered up until the 4001-5000 lei monthly income level, the 5001-6000 lei and above 6000 lei per month the percentage of respondents in these categories is higher than in the lower-income ones. In this case, income acts as a barrier in a high intake of vegetables for the lower and middle-income categories, while high-income categories have a direct relationship between income and the vegetable intake [14,39].

Combined with the distribution between female and male respondents and sustainability-related purchasing criteria considered for this study, it turns out that females are more considerate regarding the type of production (organic/conventional) and the provenance country, $13 \%$ of the female respondents and $12 \%$ of the male respondents see this as very important criteria. Thirty-three percent of the female respondents and $44 \%$ of the male respondents take into consideration where the products were grown (greenhouse/open-air). Yet, when it comes to local provenance, $77 \%$ of the females and $67 \%$ of the males report that they have a high preference for Romanian vegetables.

Based on these results, the seventh hypothesis (H7) is only partially confirmed. Female respondents have a higher preference for vegetables than men, but not due to sustainability principles. Considering sustainability criteria, men appear to have different priorities than women when considering some sustainability principles related to production type or regionality when they choose their vegetables. This confirms other studies in the field, which consider the differences within gender and age-related to vegetable consumption, proving that there are differences between men and women in what regards the vegetable choice [96,110-113]. Considering the study conducted by Piester et al. [97], the results support this study, due to the fact that without previously specifying which choice is more sustainable, the sustainability principles of vegetable choice do not differ between men and women, while the presence of the "ecologic production" option generates differences between gender choices.

The differences between sustainability principles may be generated not only by gender but also by age differences. Therefore, in Table 5 the distribution of respondents by age and sustainability principles in vegetable consumption is presented. 
Table 5. Importance of sustainability criteria in the consumption pattern by age.

\begin{tabular}{|c|c|c|c|c|c|c|c|c|c|c|c|c|c|}
\hline & & $\begin{array}{l}15-19 \\
\text { y.o. * }\end{array}$ & $\begin{array}{l}20-24 \\
\text { y.o. }\end{array}$ & $\begin{array}{l}25-29 \\
\text { y.o. * }\end{array}$ & $\begin{array}{l}30-34 \\
\text { y.o. }\end{array}$ & $\begin{array}{l}35-39 \\
\text { y.o. * }\end{array}$ & $\begin{array}{l}\text { 40-44 } \\
\text { y.o. * }\end{array}$ & $\begin{array}{l}45-49 \\
\text { y.o. }\end{array}$ & $\begin{array}{l}50-54 \\
\text { y.o. * }\end{array}$ & $\begin{array}{l}54-59 \\
\text { y.o. * }\end{array}$ & $\begin{array}{l}60-64 \\
\text { y.o. }\end{array}$ & $\begin{array}{l}>70 \\
\text { y.o. }\end{array}$ & Total \\
\hline \multirow{2}{*}{$\begin{array}{l}\text { Where they were produced } \\
\text { (open air, green house etc) (\%) }\end{array}$} & $\mathrm{Mi}^{*}$ & 0.0 & 19.6 & 3.4 & 0.9 & 1.7 & 3.7 & 2.9 & 3.2 & 0.2 & 0.9 & 0.2 & 37.2 \\
\hline & $\mathrm{Li}^{*}$ & 0.0 & 6.2 & 1.2 & 0.9 & 0.5 & 1.9 & 1.2 & 0.2 & 0.0 & 0.0 & 0.0 & 12.4 \\
\hline \multirow{2}{*}{$\begin{array}{l}\text { How they were produced } \\
\text { ecologic/conventional }(\%)\end{array}$} & $\mathrm{Mi}^{*}$ & 0.0 & 3.4 & 0.5 & 0.2 & 0.5 & 3.4 & 1.9 & 1.9 & 0.2 & 0.5 & 0.2 & 13.1 \\
\hline & $\mathrm{Li}^{*}$ & 0.0 & 2.9 & 0.7 & 0.7 & 0.2 & 1.7 & 0.9 & 0.5 & 0.0 & 0.0 & 0.0 & 7.9 \\
\hline \multirow{2}{*}{ Production country (\%) } & $\mathrm{Mi}^{*}$ & 0.0 & 2.9 & 0.5 & 1.4 & 0.7 & 3.4 & 1.2 & 1.7 & 0.2 & 0.2 & 0.2 & 12.9 \\
\hline & $\mathrm{Li}^{*}$ & 0.0 & 7.6 & 0.5 & 0.7 & 0.5 & 1.7 & 2.7 & 0.7 & 0.2 & 0.0 & 0.0 & 14.8 \\
\hline \multirow{3}{*}{$\begin{array}{l}\text { Consumption of local } \\
\text { provenance }(\%)\end{array}$} & Not at all & 100.0 & 8.2 & 3.2 & 0.0 & 0.0 & 0.0 & 3.6 & 0.0 & 0.0 & 0.0 & 0.0 & 4.5 \\
\hline & A little & 0.0 & 26.9 & 25.8 & 21.1 & 10.5 & 25.0 & 33.9 & 25.7 & 0.0 & 16.7 & 0.0 & 25.8 \\
\hline & A lot & 0.0 & 64.9 & 71.0 & 78.9 & 89.5 & 75.0 & 62.5 & 74.3 & 100.0 & 83.3 & 100.0 & 69.7 \\
\hline \multirow{3}{*}{$\begin{array}{l}\text { Consumption of international } \\
\text { provenance }(\%)\end{array}$} & Not at all & 0.0 & 9.4 & 9.7 & 10.5 & 5.3 & 8.3 & 7.1 & 0.0 & 25.0 & 0.0 & 100.0 & 8.2 \\
\hline & A little & 0.0 & 63.7 & 45.2 & 73.7 & 73.7 & 71.7 & 55.4 & 85.7 & 75.0 & 100.0 & 0.0 & 65.5 \\
\hline & A lot & 100.0 & 26.9 & 45.2 & 15.8 & 21.1 & 20.0 & 37.5 & 14.3 & 0.0 & 0.0 & 0.0 & 26.3 \\
\hline
\end{tabular}

The respondents were asked to classify by importance some vegetable choice criteria that may be considered in a sustainable diet $[29,30]$ without precisely specifying this aspect to the respondents.

When asked to provide a level of importance from 1 to 6 , the respondents were less likely to choose an extreme answer and preferred the middle levels. Yet, $19.6 \%$ of the respondents between 20 and 24 years old considered that where the vegetables are produced (greenhouse/open-air) is the most important factor in their choice decision, while the other categories of age have percentages of less than $5 \%$. The same age category (20-24 years old) provides the highest percentage of respondents who consider this criterion as the least important in their choice decision (6.2\%). The ecologic versus conventional production of vegetables is the least important criterion for all age categories. Only $3.4 \%$ in the 20-24 years old and 40-44 years old categories consider it as the most important when deciding what vegetables to buy, while $2.9 \%$ of the respondents between 20 and 24 years old see this as the least important aspect. Considering the country of provenance, the respondents were again reluctant in offering an extreme answer. The highest percentage of people considering this to be an important criterion is $3.4 \%$ in the $40-44$ years old category, while $7.6 \%$ of the respondents in the $20-24$ years old category see this as the least important.

When given fewer options to choose from, the respondents changed their opinions. Most respondents, in all age categories, consider that consuming vegetables of local provenance is especially important. The age categories representing adults (more than 35 years old) have a higher percentage than the youth for considering this criterion. When considering the consumption of vegetables of international provenance, the respondents were realistic, based on the purchasing options available in Romania, where important amounts of vegetables are imported [114]. Even if the preferred answer by all age groups is "a little", meaning that the respondents are trying to avoid imported vegetables, $45.2 \%$ of the 25-29 years old category declares that they mostly consume imported vegetables, due to the high availability all year, followed by $37.5 \%$ of the $45-49$ age category and $26.9 \%$ of the $20-24$ years old category.

Based on these results, the first hypothesis (H1) is infirmed. All age categories declare they have a high consumption of vegetables, so a significant difference by age categories is not applicable for this study, but an income-based one is relevant. The sustainability principles took into consideration for this study demonstrate that the youth do not have a more sustainable choice of vegetables than the elderly, but the opposite. The elderly respondents tend to consider consuming vegetables from local production more, even if they do not have high consideration for ecological production and the type of crops. The choice of locally grown vegetables is the most common form of expressing their sustainable choice for the respondents, correlating the results with the study of Vermeir et al. [91], and confirming the results of Voinea et al. [37] that environmental concern is not yet developed in the conscience of the Romanian consumer. Furthermore, the results suggest that the social aspect of sustainability [26] is the most pregnant one in the Romanian consumers' conscience as buying local vegetables is a direct aid for the local producers. These results cannot confirm Bumbac et al. [38] since the age differences in preferring organic and local vegetables are not significant, nevertheless, they are encouraging given the fact that there are promoters of a sustainable diet in every age category. 
In Table 6, the frequency declared by the respondents for purchasing vegetables is taken into consideration. Considering the dietary guidelines, a frequent purchasing pattern that would ensure vegetable freshness is expected, especially for respondents with higher incomes.

Table 6. Purchasing frequency based on income.

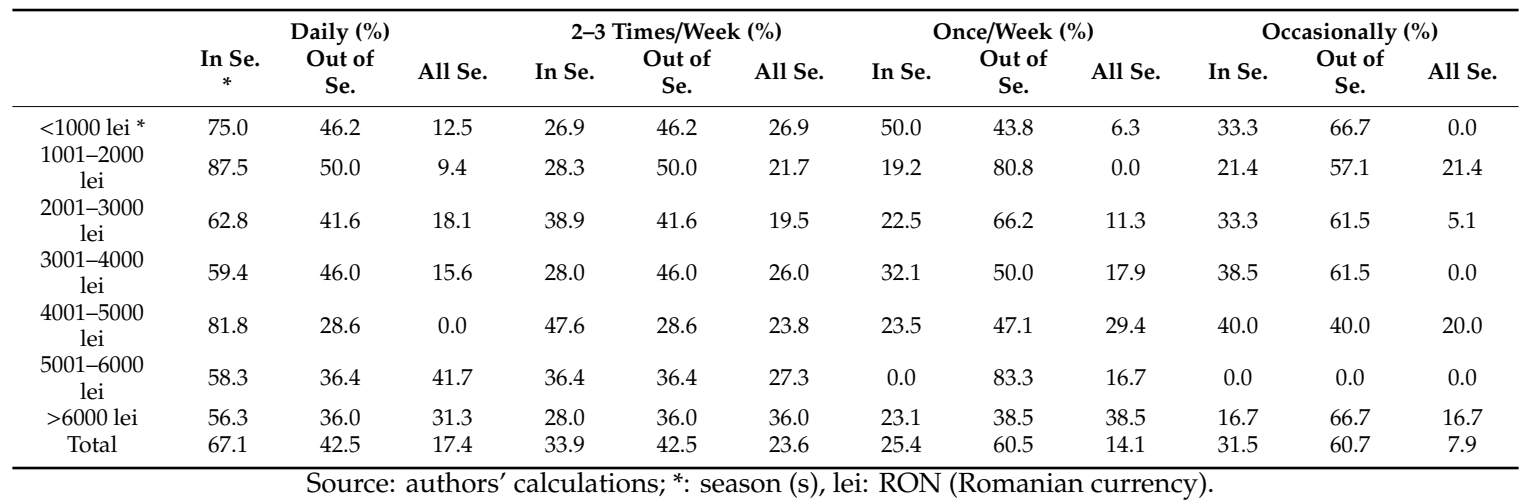

The income is an important factor in the purchasing pattern, even for food products, and is determined as a barrier by other studies [39]. It is easy to see that for respondents with lower incomes, the most frequent purchase of vegetables is encountered in-season when the availability of products is higher, and the prices are lower. The purchasing frequency declines for the lower-income categories when the vegetables run out of season. Of the respondents, $66.7 \%$ with less than 1000 lei and $57.1 \%$ of the respondents with 1000 to 2000 lei incomes buy vegetables only occasionally when out of season. The same trend is registered for respondents in the other income categories, but the differences between daily in-season and out of season purchases are smaller, except for the 4001-5000 lei income category, where the occasional purchases are the most balanced, no matter the season. Yet, the daily out of season vegetable purchases record a higher percentage for the lower-income categories than for the higher ones. It may be due to the fact that vegetables are a cheaper category of food, more accessible to lower-income categories [13]. Yet, seasonality turns out to be a sustainability aspect respected by the respondents.

For this study, a vegetable purchasing pattern based on income categories cannot be specifically determined. All income categories have a more frequent purchase when vegetables are in-season and decrease in frequency within colder seasons. Therefore, these results do not confirm the claims that higher incomes are necessary for vegetable-based diets [26,39], but they contradict them showing that the frequency of purchase is not solely an income-dependent variable.

Table 7 presents the distribution of respondents by age and their claimed willingness to pay for vegetables that have ecologic or organic certification, are of better quality, or are of local provenance.

Table 7. Willingness to pay for sustainable vegetables by age.

\begin{tabular}{|c|c|c|c|c|c|c|c|c|c|c|c|c|}
\hline Criteria for Sustainable Vegetables & $\begin{array}{l}\text { 15-19 } \\
\text { y.o. * }\end{array}$ & $\begin{array}{l}20-24 \\
\text { y.o. }\end{array}$ & $\begin{array}{c}25-29 \\
\text { y.o. }\end{array}$ & $\begin{array}{c}\text { 30-34 } \\
\text { y.o. }\end{array}$ & $\begin{array}{l}\text { 35-39 } \\
\text { y.o. }\end{array}$ & $\begin{array}{c}40-44 \\
\text { y.o. }\end{array}$ & $\begin{array}{l}45-49 \\
\text { y.o. }\end{array}$ & $\begin{array}{l}50-54 \\
\text { y.o. }\end{array}$ & $\begin{array}{c}\text { 54-59 } \\
\text { y.o. }\end{array}$ & $\begin{array}{l}60-64 \\
\text { y.o. }\end{array}$ & $\begin{array}{l}>70 \\
\text { y.o. }\end{array}$ & Total \\
\hline 1. Ecologic produced and certified (\%) & 0.0 & 8.6 & 1.7 & 0.5 & 0.2 & 2.7 & 2.4 & 2.9 & 0.2 & 0.5 & 0.0 & 20.1 \\
\hline 2. Are of superior quality $(\%)$ & 0.0 & 19.1 & 2.7 & 0.7 & 2.2 & 7.2 & 8.1 & 3.7 & 0.2 & 0.5 & 0.2 & 44.9 \\
\hline 3. Local provenance $(\%)$ & 0.0 & 2.4 & 0.7 & 0.9 & 0.5 & 0.7 & 0.7 & 0.7 & 0.0 & 0.0 & 0.0 & 6.9 \\
\hline 1 and $2(\%)$ & 0.0 & 6.7 & 0.5 & 0.2 & 0.2 & 1.2 & 0.7 & 0.2 & 0.0 & 0.0 & 0.0 & 9.9 \\
\hline 1 and $3(\%)$ & 0.0 & 0.5 & 0.2 & 0.2 & 0.5 & 0.0 & 0.0 & 0.0 & 0.0 & 0.0 & 0.0 & 1.4 \\
\hline 2 and $3(\%)$ & 0.0 & 1.2 & 0.9 & 0.5 & 0.0 & 0.5 & 0.2 & 0.5 & 0.0 & 0.2 & 0.0 & 4.2 \\
\hline 1,2 and $3(\%)$ & 0.0 & 3.7 & 0.7 & 1.4 & 0.9 & 1.2 & 1.2 & 0.2 & 0.5 & 0.0 & 0.0 & 10.1 \\
\hline
\end{tabular}

The most important criterion for paying a higher price is the "superior quality", a criterion that has been put in the questionnaire for comparing clear sustainability criteria to relative ones that are hard to pinpoint by respondents. Even so, this relative higher quality has been preferred by most of the respondents in all age categories. 
Considering the ecologically produced vegetables, $8.6 \%$ of the total number of respondents are aged between 20 and 24 years old and are willing to pay more for them, $2.4 \%$ of the respondents, in the same age category, would be willing to pay more for local vegetables. The combination between ecologic certification and local production raised the littlest interest for all age categories, only $0.5 \%$ of the respondents (ages between 20 and 24 years old and 50 to 54 years old) are willing to pay more for these products.

The third hypothesis (H3) is confirmed, the younger age categories have a slightly higher willingness to pay for more sustainable vegetables. However, they do not know, very well, what are the quality criteria that should be considered in their choice, confirming the studies that claim a significant need for education towards sustainable and healthy consumption patterns [76,77]. Based on these results, the results of [38] are confirmed, younger consumers having a higher interest in local and organic grown food.

Developing on the purchasing pattern for the respondents to this study, the possible differences between age categories are presented in Table 8.

Table 8. Purchasing preferences by age.

\begin{tabular}{|c|c|c|c|c|c|c|c|c|c|c|c|c|c|}
\hline Source & Freq & $\begin{array}{c}\text { 15-19 } \\
\text { y.o. }\end{array}$ & $\begin{array}{l}20-24 \\
\text { y.o. }\end{array}$ & $\begin{array}{c}25-29 \\
\text { y.o. }\end{array}$ & $\begin{array}{c}\text { 30-34 } \\
\text { y.o. }\end{array}$ & $\begin{array}{c}\text { 35-39 } \\
\text { y.o. }\end{array}$ & $\begin{array}{l}\text { 40-44 } \\
\text { y.o. }\end{array}$ & $\begin{array}{l}45-49 \\
\text { y.o. }\end{array}$ & $\begin{array}{c}\text { 50-54 } \\
\text { y.o. }\end{array}$ & $\begin{array}{c}54-59 \\
\text { y.o. }\end{array}$ & $\begin{array}{l}\text { 60-64 } \\
\text { y.o. }\end{array}$ & $\begin{array}{l}>70 \\
\text { y.o. }\end{array}$ & Total \\
\hline \multirow{5}{*}{$\begin{array}{c}\text { Own } \\
\text { production } \\
(\%)\end{array}$} & 1 & 0.0 & 29.2 & 38.7 & 42.1 & 26.3 & 31.7 & 42.9 & 42.9 & 75.0 & 0.0 & 0.0 & 33.7 \\
\hline & 2 & 0.0 & 26.9 & 25.8 & 26.3 & 21.1 & 28.3 & 10.7 & 11.4 & 0.0 & 33.3 & 0.0 & 22.8 \\
\hline & 3 & 100.0 & 18.1 & 6.5 & 10.5 & 36.8 & 18.3 & 16.1 & 17.1 & 25.0 & 50.0 & 0.0 & 18.1 \\
\hline & 4 & 0.0 & 12.3 & 9.7 & 5.3 & 5.3 & 11.7 & 25.0 & 14.3 & 0.0 & 16.7 & 0.0 & 13.2 \\
\hline & 5 & 0.0 & 13.5 & 19.4 & 15.8 & 10.5 & 10.0 & 5.4 & 14.3 & 0.0 & 0.0 & 100.0 & 12.2 \\
\hline \multirow{5}{*}{$\begin{array}{l}\text { Local } \\
\text { producers } \\
(\%)\end{array}$} & 1 & 0.0 & 19.9 & 19.4 & 36.8 & 15.8 & 21.7 & 26.8 & 5.7 & 0.0 & 0.0 & 0.0 & 19.9 \\
\hline & 2 & 0.0 & 26.3 & 25.8 & 15.8 & 26.3 & 25.0 & 21.4 & 25.7 & 25.0 & 16.7 & 0.0 & 24.6 \\
\hline & 3 & 0.0 & 21.6 & 16.1 & 21.1 & 31.6 & 25.0 & 23.2 & 31.4 & 50.0 & 16.7 & 0.0 & 23.3 \\
\hline & 4 & 0.0 & 22.8 & 32.3 & 26.3 & 21.1 & 23.3 & 25.0 & 28.6 & 0.0 & 50.0 & 0.0 & 24.6 \\
\hline & 5 & 100.0 & 9.4 & 6.5 & 0.0 & 5.3 & 5.0 & 3.6 & 8.6 & 25.0 & 16.7 & 100.0 & 7.7 \\
\hline \multirow{5}{*}{$\begin{array}{c}\text { Food } \\
\text { markets (\%) }\end{array}$} & 1 & 0.0 & 11.1 & 6.5 & 5.3 & 5.3 & 5.0 & 3.6 & 0.0 & 0.0 & 0.0 & 0.0 & 6.9 \\
\hline & 2 & 0.0 & 13.5 & 9.7 & 26.3 & 26.3 & 16.7 & 14.3 & 20.0 & 50.0 & 0.0 & 0.0 & 15.6 \\
\hline & 3 & 0.0 & 24.6 & 19.4 & 31.6 & 31.6 & 18.3 & 21.4 & 25.7 & 0.0 & 16.7 & 0.0 & 23.1 \\
\hline & 4 & 0.0 & 30.4 & 45.2 & 36.8 & 21.1 & 38.3 & 50.0 & 42.9 & 25.0 & 33.3 & 0.0 & 36.2 \\
\hline & 5 & 100.0 & 20.5 & 19.4 & 0.0 & 15.8 & 21.7 & 10.7 & 11.4 & 25.0 & 50.0 & 100.0 & 18.1 \\
\hline \multirow{5}{*}{$\begin{array}{l}\text { Convenience } \\
\text { stores (\%) }\end{array}$} & 1 & 0.0 & 15.8 & 6.5 & 31.6 & 15.8 & 18.3 & 16.1 & 11.4 & 25.0 & 16.7 & 0.0 & 15.9 \\
\hline & 2 & 0.0 & 15.2 & 29.0 & 10.5 & 15.8 & 21.7 & 19.6 & 22.9 & 25.0 & 33.3 & 0.0 & 18.6 \\
\hline & 3 & 0.0 & 27.5 & 16.1 & 31.6 & 36.8 & 23.3 & 35.7 & 37.1 & 0.0 & 16.7 & 0.0 & 28.0 \\
\hline & 4 & 100.0 & 28.7 & 25.8 & 21.1 & 31.6 & 30.0 & 19.6 & 14.3 & 50.0 & 33.3 & 0.0 & 26.3 \\
\hline & 5 & 0.0 & 12.9 & 22.6 & 5.3 & 0.0 & 6.7 & 8.9 & 14.3 & 0.0 & 0.0 & 100.0 & 11.2 \\
\hline \multirow{5}{*}{$\begin{array}{l}\text { Supermarkets } \\
(\%)\end{array}$} & 1 & 0.0 & 7.0 & 3.2 & 5.3 & 0.0 & 8.3 & 1.8 & 2.9 & 0.0 & 0.0 & 0.0 & 5.2 \\
\hline & 2 & 0.0 & 9.4 & 12.9 & 10.5 & 5.3 & 8.3 & 12.5 & 14.3 & 0.0 & 16.7 & 0.0 & 10.2 \\
\hline & 3 & 0.0 & 10.5 & 0.0 & 15.8 & 15.8 & 8.3 & 7.1 & 25.7 & 0.0 & 50.0 & 0.0 & 11.2 \\
\hline & 4 & 0.0 & 29.2 & 45.2 & 36.8 & 47.4 & 36.7 & 39.3 & 28.6 & 50.0 & 16.7 & 0.0 & 34.0 \\
\hline & 5 & 100.0 & 43.9 & 38.7 & 31.6 & 31.6 & 38.3 & 39.3 & 28.6 & 50.0 & 16.7 & 100.0 & 39.5 \\
\hline \multirow{5}{*}{$\begin{array}{c}\text { Online stores } \\
(\%)\end{array}$} & 1 & 100.0 & 72.5 & 64.5 & 84.2 & 78.9 & 80.0 & 91.1 & 88.6 & 100.0 & 100.0 & 0.0 & 78.4 \\
\hline & 2 & 0.0 & 10.5 & 19.4 & 15.8 & 5.3 & 6.7 & 3.6 & 8.6 & 0.0 & 0.0 & 0.0 & 9.2 \\
\hline & 3 & 0.0 & 4.7 & 3.2 & 0.0 & 15.8 & 5.0 & 5.4 & 0.0 & 0.0 & 0.0 & 0.0 & 4.5 \\
\hline & 4 & 0.0 & 4.1 & 3.2 & 0.0 & 0.0 & 5.0 & 0.0 & 2.9 & 0.0 & 0.0 & 0.0 & 3.0 \\
\hline & 5 & 0.0 & 8.2 & 9.7 & 0.0 & 0.0 & 3.3 & 0.0 & 0.0 & 0.0 & 0.0 & 100.0 & 5.0 \\
\hline \multirow{5}{*}{ En-gros (\%) } & 1 & 0.0 & 59.6 & 54.8 & 84.2 & 63.2 & 71.7 & 76.8 & 54.3 & 75.0 & 83.3 & 0.0 & 64.5 \\
\hline & 2 & 0.0 & 13.5 & 29.0 & 10.5 & 15.8 & 11.7 & 16.1 & 28.6 & 0.0 & 16.7 & 0.0 & 15.9 \\
\hline & 3 & 100.0 & 11.7 & 3.2 & 5.3 & 10.5 & 13.3 & 1.8 & 11.4 & 25.0 & 0.0 & 0.0 & 9.7 \\
\hline & 4 & 0.0 & 6.4 & 6.5 & 0.0 & 10.5 & 1.7 & 5.4 & 5.7 & 0.0 & 0.0 & 0.0 & 5.2 \\
\hline & 5 & 0.0 & 8.8 & 6.5 & 0.0 & 0.0 & 1.7 & 0.0 & 0.0 & 0.0 & 0.0 & 100.0 & 4.7 \\
\hline
\end{tabular}

Source: authors' calculations; Legend: 1: Not at all; 2: Verry rare; 3: Rare; 4: Often; 5: Very often. The highest and

lowest values are in bold.

Growing your own vegetables has become a recent trend, due to reasons such as security of production, therapeutical activities, or leisure activities, but the economic component is not precisely relevant to this trend $[115,116]$. Therefore, people who consume more vegetables from their own production than from other sources are more likely to be occupied in agriculture, than for any other reason. For this study, younger age categories have a higher percentage, reported to their age category, for preferring vegetables from their own production.

Food markets and local producers have similar results, due to the fact that local producers are often encountered in food markets and less in other types of selling facilities. The results do not show any age generated patterns for choosing local producers and food markets, a fact that contradicts 
the previous claims of the respondents who preferred locally grown vegetables. Considering the supermarket and the convenience store as a source for vegetables, there is a slightly higher preference for it from the older age categories, while the online stores are only considered a source by the younger categories. Additionally, purchasing in high quantities is an option for younger categories, and less for older ones. Therefore, the fourth hypothesis (H4) is partially confirmed, there is a higher preference for purchasing vegetables from supermarkets and convenience stores from older categories of respondents, while the younger ones do not seem to prefer the local producers or the food markets in a significant way. The results indicate that the Romanian consumers are not willing to sacrifice their time for seeking locally grown vegetables in food markets or to identify local producers, but they expect them to be in supermarkets, and on a smaller scale, online, therefore confirming previous studies [78].

An important component in developing a sustainable consumption pattern is learning how much to buy to waste fewer products and learning ways of preparing them for prolonging their consumption period, such as conservation. High availability of vegetables in-season might be equivalent to a higher waste proportion, especially for higher-income categories where affordability is a smaller issue. In the Table 9 , the differences of wasted vegetables by income categories are presented.

Table 9. Percentage of wasted vegetables by season and income.

\begin{tabular}{|c|c|c|c|c|c|c|c|c|c|}
\hline $\begin{array}{l}\text { Criteria for } \\
\text { Sustainable } \\
\text { Vegetables }\end{array}$ & Season & $<1000$ Lei & $\begin{array}{c}\text { 1001-2000 } \\
\text { Lei }\end{array}$ & $\begin{array}{c}\text { 2001-3000 } \\
\text { Lei }\end{array}$ & $\begin{array}{c}\text { 3001-4000 } \\
\text { Lei }\end{array}$ & $\begin{array}{c}\text { 4001-5000 } \\
\text { Lei }\end{array}$ & $\begin{array}{c}\text { 5001-6000 } \\
\text { Lei }\end{array}$ & $>6000$ Lei & Total \\
\hline \multirow[b]{2}{*}{$<10 \%$} & \multirow{2}{*}{$\begin{array}{c}\text { In season } \\
\text { Out of } \\
\text { season }\end{array}$} & 26.5 & 16.9 & 21.2 & 26.1 & 34.5 & 31.6 & 21.6 & 23.3 \\
\hline & & 29.4 & 22.0 & 34.6 & 31.9 & 41.4 & 42.1 & 24.3 & 31.8 \\
\hline \multirow[b]{2}{*}{$10 \%$} & \multirow{2}{*}{$\begin{array}{c}\text { In season } \\
\text { Out of } \\
\text { season }\end{array}$} & 20.6 & 15.3 & 14.7 & 13.0 & 20.7 & 15.8 & 21.6 & 16.1 \\
\hline & & 23.5 & 20.3 & 16.0 & 18.8 & 20.7 & 15.8 & 35.1 & 19.9 \\
\hline \multirow[b]{2}{*}{$20 \%$} & \multirow{2}{*}{$\begin{array}{c}\text { In season } \\
\text { Out of } \\
\text { season }\end{array}$} & 20.6 & 20.3 & 34.0 & 23.2 & 10.3 & 21.1 & 27.0 & 26.1 \\
\hline & & 17.6 & 16.9 & 21.8 & 13.0 & 10.3 & 0.0 & 21.6 & 17.4 \\
\hline \multirow[b]{2}{*}{$30 \%$} & \multirow{2}{*}{$\begin{array}{c}\text { In season } \\
\text { Out of } \\
\text { season }\end{array}$} & 11.8 & 13.6 & 14.1 & 18.8 & 24.1 & 5.3 & 18.9 & 15.4 \\
\hline & & 14.7 & 13.6 & 11.5 & 20.3 & 13.8 & 10.5 & 10.8 & 13.6 \\
\hline \multirow[b]{2}{*}{$40 \%$} & \multirow{2}{*}{$\begin{array}{c}\text { In season } \\
\text { Out of } \\
\text { season }\end{array}$} & 11.8 & 13.6 & 2.6 & 7.2 & 6.9 & 5.3 & 5.4 & 6.5 \\
\hline & & 5.9 & 15.3 & 6.4 & 2.9 & 3.4 & 15.8 & 2.7 & 6.9 \\
\hline \multirow[b]{2}{*}{$50 \%$} & \multirow{2}{*}{$\begin{array}{l}\text { In season } \\
\text { Out of } \\
\text { season }\end{array}$} & 2.9 & 5.1 & 4.5 & 4.3 & 3.4 & 5.3 & 0.0 & 4.0 \\
\hline & & 2.9 & 8.5 & 5.1 & 2.9 & 3.4 & 5.3 & 0.0 & 4.5 \\
\hline \multirow[b]{2}{*}{$60 \%$} & \multirow{2}{*}{$\begin{array}{l}\text { In season } \\
\text { Out of } \\
\text { season }\end{array}$} & 2.9 & 6.8 & 3.8 & 4.3 & 0.0 & 5.3 & 2.7 & 4.0 \\
\hline & & 5.9 & 1.7 & 2.6 & 4.3 & 6.9 & 10.5 & 5.4 & 4.0 \\
\hline \multirow[b]{2}{*}{$70 \%$} & \multirow{2}{*}{$\begin{array}{l}\text { In season } \\
\text { Out of } \\
\text { season }\end{array}$} & 2.9 & 8.5 & 5.1 & 2.9 & 0.0 & 10.5 & 2.7 & 4.7 \\
\hline & & 0.0 & 1.7 & 1.9 & 5.8 & 0.0 & 0.0 & 0.0 & 2.0 \\
\hline
\end{tabular}

For the most desirable option, a waste of less than $10 \%$ of the purchased vegetables is the most significant option for the lowest income category, followed by an approximate $10 \%$ waste. The increase in waste is directly proportional to a decrease in respondents wasting that many vegetables. Yet, more vegetables are wasted out of season than in-season by this category of age, as it is the case for all age categories regarding wasting $10 \%$ or less from the total amount of vegetables purchased.

The proportions of wasted vegetables are higher for respondents in higher-income categories only in what regards a waste below $40 \%$. Above that level, the percentage of respondents who declare their waste is lower than that are the low- and middle-income categories. The proportion of vegetables wasted when out of season is overall lower than in-season.

The fifth hypothesis is confirmed if the waste below $40 \%$ is considered. People with higher incomes have the tendency to waste more than people with low and middle incomes when it comes to vegetables. For levels of waste above $40 \%$ of the respondents in each income category are similar, but their percentage is considerably low, given the number of respondents in each category. Considering 
the vegetable waste pattern for the respondents and previous studies [57], the Romanian vegetable consumers do not have a significantly unsustainable diet. As is, their tendency to waste little is a sustainable one that needs further improvement.

Table 10 presents the distribution of respondents by income categories and by the importance they give to purchasing criteria, other than sustainability-related ones.

Table 10. Importance of criteria in the purchasing decision of vegetables by income

\begin{tabular}{|c|c|c|c|c|c|c|c|c|}
\hline Criteria & $\begin{array}{c}\text { Importance } \\
\text { Level * }\end{array}$ & $\begin{array}{c}<1000 \\
\text { Lei }\end{array}$ & $\begin{array}{l}\text { 1001-2000 } \\
\text { Lei }\end{array}$ & $\begin{array}{l}\text { 2001-3000 } \\
\text { Lei }\end{array}$ & $\begin{array}{l}\text { 3001-4000 } \\
\text { Lei }\end{array}$ & $\begin{array}{l}\text { 4001-5000 } \\
\text { Lei }\end{array}$ & $\begin{array}{l}\text { 5001-6000 } \\
\text { Lei }\end{array}$ & $\begin{array}{c}>6000 \\
\text { Lei }\end{array}$ \\
\hline \multirow{6}{*}{ Price (\%) } & 1 & 1.7 & 4.0 & 5.7 & 2.5 & 1.2 & 0.5 & 1.5 \\
\hline & 2 & 1.7 & 3.7 & 4.7 & 3.7 & 1.2 & 0.0 & 1.7 \\
\hline & 3 & 2.2 & 3.5 & 13.4 & 5.2 & 2.5 & 1.2 & 3.0 \\
\hline & 4 & 2.0 & 2.0 & 9.7 & 2.5 & 1.5 & 1.0 & 1.2 \\
\hline & 5 & 0.5 & 1.5 & 2.0 & 3.0 & 0.7 & 1.0 & 1.2 \\
\hline & 6 & 0.2 & 0.0 & 3.2 & 0.2 & 0.0 & 1.0 & 0.5 \\
\hline \multirow{6}{*}{ Quality (\%) } & 1 & 2.7 & 6.7 & 12.9 & 6.7 & 4.2 & 2.0 & 4.7 \\
\hline & 2 & 1.2 & 3.0 & 3.2 & 2.5 & 0.5 & 0.2 & 0.5 \\
\hline & 3 & 1.2 & 1.5 & 4.5 & 2.0 & 1.0 & 0.5 & 0.5 \\
\hline & 4 & 2.0 & 2.2 & 11.4 & 3.5 & 1.0 & 1.2 & 1.5 \\
\hline & 5 & 1.0 & 0.7 & 3.0 & 1.0 & 0.5 & 0.2 & 0.7 \\
\hline & 6 & 0.2 & 0.5 & 3.7 & 1.5 & 0.0 & 0.5 & 1.2 \\
\hline \multirow{6}{*}{$\begin{array}{c}\text { Promotions } \\
\quad(\%)\end{array}$} & 1 & 1.5 & 1.7 & 4.7 & & 0.5 & 0.5 & 0.7 \\
\hline & 2 & 0.7 & 1.0 & 4.2 & 2.7 & 0.5 & 0.2 & 1.2 \\
\hline & 3 & 1.2 & 3.2 & 6.0 & 2.7 & 2.0 & 0.5 & 1.2 \\
\hline & 4 & 0.7 & 2.5 & 2.7 & 2.2 & 1.2 & 0.2 & 1.5 \\
\hline & 5 & 1.0 & 1.2 & 5.5 & 2.0 & 0.7 & 0.7 & 2.0 \\
\hline & 6 & 3.2 & 5.0 & 15.6 & 6.2 & 2.2 & 2.5 & 2.5 \\
\hline
\end{tabular}

Source: authors' calculations; ${ }^{*} 1$ is the most important; 6 is the least important. The highest and lowest values are in bold.

Calculated as a percentage of the total number of respondents, the answers to this question show that the middle-income category has the highest interest in criteria related to price, quality, and promotions for vegetables. Price is determined as more important for the low-income categories, along with promotions, while the higher income categories declare them as not important criteria and prefer the quality of their purchased vegetables. Quality is appreciated through sensorial evaluation (color, aspect, freshness, taste). Among these, freshness provides valuable insights, due to the fact that fresh-looking vegetables might be produced in a closer area, receive fewer treatments for preservation, and be transported over a smaller distance, therefore they should be more sustainable. Almost half of the respondents consider freshness as an important criterion in the purchasing decision, followed by taste, looks, and color. It is important to mention that the appreciation of freshness in the purchasing decision increases along with the age of the respondents.

Therefore, the sixth hypothesis considered for this study is confirmed, a higher level of income generates more appreciation for the quality of the purchased vegetables than their price or available offers. In this case, presenting the sustainable vegetables as of higher quality through specific labeling would offer the consumers the option of easily identifying them in stores or markets and, therefore, satisfy their need for quality purchases while having a sustainable diet, an idea that correlates with previous studies $[85,101]$.

\section{Conclusions}

The present study contributes to determining whether the Romanian food consumers have the possibility of following the dietary recommendations regarding vegetable consumption. This was done by constructing an extensive image of the current stage of vegetable consumption of a respondent sample that is significant for the population with ages above 15 years old. 
The respondents to this study appreciate their vegetable consumption as very important in their diets, female respondents had a higher consumption of vegetables than male respondents while considering the age distribution, the majority appreciates having a high or very high vegetable intake. Considering sustainability-related criteria in the choice and consumption of vegetables, the respondents demonstrate that they do not have a conscious environmental concern, validating previous results in the field [37]. Yet, their choices, while uneducated towards sustainability, do have some natural or unconscious sustainability reasoning that might be used in a conscious guiding towards sustainable food choices and diets. For example, the respondents are more inclined to choose a locally produced vegetable that is in-season than an imported vegetable also in-season, but they are limited in their choice by the high availability and sometimes higher affordability of imported vegetables all-year-round. Therefore, favoring a higher availability for the locally produced vegetables at affordable prices in colder seasons would contribute to developing the sustainable behavior of Romanian consumers.

Around $50 \%$ of the respondents are guided by freshness when evaluating vegetable quality, therefore another sustainability criterion is used by the consumers without knowing to associate it with a new consumption pattern, but to common sense. Yet, middle to higher income categories validates the assumptions according to which a meat-based diet is a form of showing social status. Therefore, targeted messages for these income categories might contribute to changing this perception.

Younger age categories seem to have an increased preference for local producers and food markets than older age categories. Favoring local producers in selling their vegetables in supermarkets or convenience stores might generate an increase in choosing local vegetables for people with little time for shopping and for older age categories.

The respondents to this study are not characterized by an acknowledged sustainability purchasing behavior when it comes to their vegetable consumption, but that does not mean they have a totally unsustainable consumption. Guided by income and time availability restrictions, by emotional choice when it comes to "ecologic" labels, by health principles, social responsibility or simple vegetable availability manifested through seasonality, the respondents take the unconscious sustainable choice when purchasing vegetables, because it probably serves their nutritional, social, economic, and even psychological needs.

Yet, the general preferences of consumers and their tendencies towards sustainability reach certain breaking points when the regular pattern of consumption loses all shape. Such a breaking point is the recently encountered COVID-19 pandemic, a situation that differs from other world crises through its novelty and unexpected implications. As statistics pointed out, one of the common reactions of the consumers was to stock up on food products with long expiration terms. The unnecessary quantities of food bought at the beginning of the pandemic had soon become waste. These consumption abnormalities have disastrous effects especially on small producers which rely on their daily customers for continuing their activity.

While some producers looked to the digital market for continuing their activity, others have not had the possibility to do so and their small business faced insolvency.

At the national level, the budget underwent structure modifications to support the health system and provide a safety net for people who lost their business or jobs. Yet, support programs for small farmers or specific vegetables were sacrificed, at the expense of threatening food security.

Acting upon these common-sense sustainable choices of the respondents should be a priority for Romanian policymakers to favor accessibility to local and seasonal vegetables at fair prices. They should also increase the visibility for these products and provide national campaigns for increasing the consumer knowledge on the possibility of consciously choosing sustainable vegetables and having a sustainable consumption pattern, even in times of crisis. It is interesting to see that in a world that claims to be seeking normality and has an ocean of open information available, the common-sense actions, such as consuming local fresh vegetables for supporting both the immune system and the small producers, are not considered while we wait for a universal cure. 
Author Contributions: The authors worked together for this research, but, per structure, conceptualization G.-R.L., M.C.D. and D.M.I., methodology, software validation and resources, G.-R.L., M.C.D., I.L.P. and F.M., formal analysis, G.-R.L., M.C.D. and V.L., writing—original draft preparation, and writing-review and editing, G.-R.L., M.C.D. and I.L.P. All authors have read and agreed to the published version of the manuscript.

Funding: This research received no external funding.

Acknowledgments: This paper is the result of the ADER 24.1.1 project: "Research on development of studies and analyzes, for the substantiation of public decisions and policies, for the marketing of agri-food products in order to ensure the food security and safety for the population".

Limitations: This study offers a static image of the Romanian vegetable consumer through empirical research. In order to provide a better image, a longitudinal study should follow the current one, at a larger scale, in order to provide a long-term evolution of the Romanian vegetable consumer. Other variables may be also considered in describing the Romanian vegetable consumer behavior.

Conflicts of Interest: The authors declare no conflict of interest.

\section{References}

1. Wallace, T.C.; Bailey, R.L.; Blumberg, J.B.; Burton-Freeman, B.; Chen, C.O.; Crowe-White, K.M.; Murray, R. Fruits, vegetables, and health: A comprehensive narrative, umbrella review of the science and recommendations for enhanced public policy to improve intake. Crit. Rev. Food Sci. Nutr. 2020, 60, 2174-2211. [CrossRef] [PubMed]

2. Pourrostami, K.; Heshmat, R.; Hemati, Z.; Heidari-Beni, M.; Qorbani, M.; Motlagh, M.E.; Taheri, M. Association of fruit and vegetable intake with meal skipping in children and adolescents: The CASPIAN-V study. Eating and Weight Disorders-Studies on Anorexia. Bulim. Obes. 2020, 25, 903-910.

3. Lonnie, M.; Johnstone, A.M. The public health rationale for promoting plant protein as an important part of a sustainable and healthy diet. Nutr. Bull. 2020, 45, 281-293. [CrossRef]

4. Anderson, H.; Falkenberg, T. The role and status of food and nutrition literacy in Canadian school curricula. Alta. J. Educ. Res. 2016, 62, 87-109.

5. Sarti, A.; Dijkstra, C.; Nury, E.; Seidell, J.C.; Dedding, C. 'I Eat the Vegetables because I Have Grown them with My Own Hands': Children's Perspectives on School Gardening and Vegetable Consumption. Child. Soc. 2017, 31, 429-440. [CrossRef]

6. Amahmid, O.; El Guamri, Y.; Rakibi, Y.; Yazidi, M.; Razoki, B.; Kaid Rassou, K.; Belghyti, D. Nutrition education in school curriculum: Impact on adolescents' attitudes and dietary behaviours. Int. J. Health Promot. Educ. 2019, 58, 1-17. [CrossRef]

7. Cotton, W.; Dudley, D.; Peralta, L.; Werkhoven, T. The effect of teacher-delivered nutrition education programs on elementary-aged students: An updated systematic review and meta-analysis. Prev. Med. Rep. 2020, 20, 101178. [CrossRef]

8. Hidalgo, D.M.; Witten, I.; Nunn, P.D.; Burkhart, S.; Bogard, J.R.; Beazley, H.; Herrero, M. Sustaining healthy diets in times of change: Linking climate hazards, food systems and nutrition security in rural communities of the Fiji Islands. Reg. Environ. Chang. 2020, 20, 73. [CrossRef]

9. Heusala, H.; Sinkko, T.; Mogensen, L.; Knudsen, M.T. Carbon footprint and land use of food products containing oat protein concentrate. J. Clean. Prod. 2020, 276, 122938. [CrossRef]

10. Santiago, E.; Eck, K.M.; Delaney, C.; Famodu, O.A.; Olfert, M.D.; Shelnutt, K.P.; Byrd-Bredbenner, C. "It's Good, It's Delicious, It's Great": Cognitions, barriers, and supports for fruit and vegetable intake of parents and school-aged children. Top. Clin. Nutr. 2019, 34, 100-113. [CrossRef]

11. Becaria Coquet, J.; Caballero, V.R.; Camisasso, M.C.; González, M.F.; Niclis, C.; Román, M.D.; Aballay, L.R. Diet Quality, Obesity and Breast Cancer Risk: An Epidemiologic Study in Córdoba, Argentina. Nutr. Cancer 2020, 72, 1026-1035. [CrossRef] [PubMed]

12. Angeles-Agdeppa, I.; Lenighan, Y.M.; Jacquier, E.F.; Toledo, M.B.; Capanzana, M.V. The Impact of Wealth Status on Food Intake Patterns in Filipino School-Aged Children and Adolescents. Nutrients 2019, 11, 2910. [CrossRef] [PubMed]

13. Diaconeasa, M.C.; Zaharia, A.; Constantin, F. Food consumption trends. May we speak about individual sustainable consumption? In Vision 2025: Education Excellence and Management of Innovations Through Sustainable Economic Competitive Advantage; 34th International-Business-Information-Management-Association (IBIMA): Spain, Madrid, 2019; pp. 6535-6544. 
14. United Nations. Sustainable Development Goals. Second Goal. Targets and Objectives. Available online: https://sdgs.un.org/goals/goal2 (accessed on 18 September 2020).

15. USDA. 2015-2020 Dietary Guidelines for Americans. 2018. Available online: https://health.gov/our-work/ food-nutrition/2015-2020-dietary-guidelines/guidelines/ (accessed on 15 September 2020).

16. The World Health Organization. Food based dietary guidelines in the WHO European Region. 2003. Available online: https://www.euro.who.int/_data/assets/pdf_file/0017/150083/E79832.pdf (accessed on 18 September 2020).

17. Australian Government. Australian Dietary Guidelines. 2013. Available online: https://www.eatforhealth. gov.au/guidelines (accessed on 15 September 2020).

18. WHO. Development of the Food Based Dietary Guidelines for the Asian Region. 1997. Available online: https: //www.who.int/nutrition/publications/nutrientrequirements/SEA_NUT_Meet_Inf.1.pdf?ua=1 (accessed on 16 September 2020).

19. Indian National Institute of Nutrition. Dietary Guidelines for Indians. 2018. Available online: https: //www.nin.res.in/downloads/DietaryGuidelinesforNINwebsite.pdf (accessed on 16 September 2020).

20. Canadian Government. Canada's Food Guide. 2019. Available online: https://food-guide.canada.ca/en/ guidelines/ (accessed on 16 September 2020).

21. Livingstone, K.; McNaughton, S. Dietary patterns by reduced rank regression are associated with obesity and hypertension in Australian adults. Br. J. Nutr. 2017, 117, 248-259. [CrossRef] [PubMed]

22. Perignon, M.; Sinfort, C.; El Ati, J.; Traissac, P.; Drogue, S.; Darmon, N.; El Ati, J. How to meet nutritional recommendations and reduce diet environmental impact in the Mediterranean region? An optimization study to identify more sustainable diets in Tunisia. Glob. Food Secur. 2019, 23, 227-235. [CrossRef]

23. Van Bussel, L.M.; Van Rossum, C.T.; Temme, E.H.; Boon, P.E.; Ocké, M.C. Educational differences in healthy, environmentally sustainable and safe food consumption among adults in the Netherlands. Public Health Nutr. 2020, 23, 1-11. [CrossRef]

24. Huyard, C. Sustainable food education: What food preparation competences are needed to support vegetable consumption? Environ. Educ. Res. 2020, 26, 1164-1176. [CrossRef]

25. Trautwein, E.A.; McKay, S. The Role of Specific Components of a Plant-Based Diet in Management of Dyslipidemia and the Impact on Cardiovascular Risk. Nutrients 2020, 12, 2671. [CrossRef]

26. Hansmann, R.; Baur, I.; Binder, C.R. Increasing organic food consumption: An integrating model of drivers and barriers. J. Clean. Prod. 2020, 275, 123058. [CrossRef]

27. Van Geffen, L.; van Herpen, E.; Sijtsema, S.J. A broader perspective on household food waste: A call for encompassing consumers' food related goals, the food system, and the impact of reduction activities. Resour. Conserv. Recycl. 2020, 163. [CrossRef]

28. Pérez-Caselles, C.; Brugarolas, M.; Martínez-Carrasco, L. Traditional Varieties for Local Markets: A Sustainable Proposal for Agricultural SMEs. Sustainability 2020, 12, 4517. [CrossRef]

29. Ansari, L.E.; Chenoune, R.; Yigezu, Y.A.; Gary, C.; Belhouchette, H. Trade-Offs between Sustainability Indicators in Response to the Production Choices of Different Farm Household Types in Drylands. Agronomy 2020, 10, 998. [CrossRef]

30. Ridoutt, B.; Anastasiou, K.; Baird, D.; Garcia, J.N.; Hendrie, G. Cropland Footprints of Australian Dietary Choices. Nutrients 2020, 12, 1212. [CrossRef] [PubMed]

31. Steenson, S.; Buttriss, J.L. The challenges of defining a healthy and 'sustainable'diet. Nutr. Bull. 2020, 45, 206-222. [CrossRef]

32. Sadhukhan, J.; Dugmore, T.I.; Matharu, A.; Martinez-Hernandez, E.; Aburto, J.; Rahman, P.K.; Lynch, J. Perspectives on "game changer" global challenges for sustainable 21st century: Plant-based diet, unavoidable food waste biorefining, and circular economy. Sustainability 2020, 12, 1976. [CrossRef]

33. Yin, J.; Yang, D.; Zhang, X.; Zhang, Y.; Cai, T.; Hao, Y.; Chen, Y. Diet shift: Considering environment, health and food culture. Sci. Total. Environ. 2020, 719, 137484. [CrossRef] [PubMed]

34. Georgescu., F. Creșterea Economică, Dezvoltarea României și Reducerea Sărăciei. Available online: https://www. researchgate.net/publication/340102267_Cresterea_economica_dezvoltarea_Romaniei_si_reducerea_saraciei (accessed on 18 September 2020).

35. National Institute of Statistics. Rata Riscului de Saracie Sau Excluziune Sociala (Poverty and Social Exclusion Rate). Available online: http://statistici.insse.ro:8077/tempo-online/\#/pages/tables/insse-table (accessed on 18 September 2020). 
36. Eurostat. Real GDP. Available online: https://ec.europa.eu/eurostat/web/sdi/decent-work-and-economicgrowth (accessed on 18 September 2020).

37. Voinea, L.; Popescu, D.V.; Bucur, M.; Negrea, T.M.; Dina, R.; Enache, C. Reshaping the Traditional Pattern of Food Consumption in Romania through the Integration of Sustainable Diet Principles. A Qualitative Study. Sustainability 2020, 12, 5826. [CrossRef]

38. Bumbac, R.; Bobe, M.; Procopie, R.; Pamfilie, R.; Giuscă, S.; Enache, C. How Zoomers' Eating Habits Should be Considered in Shaping the Food System for 2030-A Case Study on the Young Generation from Romania. Sustainability 2020, 12, 7390. [CrossRef]

39. Ion, R.A.; Popescu, C.G. Income Influence on Diet And Health. Qual. Access Success 2018, 19, $254-259$.

40. Whiting, K.; Konstantakos, L.; Carrasco, A.; Carmona, L.G. Sustainable development, wellbeing and material consumption: A stoic perspective. Sustainability 2018, 10, 474. [CrossRef]

41. Khan, S.; Dialynas, E.; Kasaraneni, V.K.; Angelakis, A.N. Similarities of Minoan and Indus Valley hydro-technologies. Sustainability 2020, 12, 4897. [CrossRef]

42. Li, Y.; Cheng, H.; Beeton, R.J.; Sigler, T.; Halog, A. Sustainability from a Chinese cultural perspective: The implications of harmonious development in environmental management. Environ. Dev. Sustain. 2016, 18, 679-696. [CrossRef]

43. Karandaeva, T.A.; Bilaonova, M.U.; Ilynichna, Z.V.; Purynycheva, G.M.; Timurgalieva, L.A. Mythological thinking as a factor of creating an innovative approach in the formation of ecological thinking. Int. Multidiscip. Sci. GeoConf. SGEM 2018, 18, 661-666.

44. Ianovali, D.; Adams, C.; Ribeiro Filho, A.A.; Khatounian, C.A. Produtividade agrícola e mudanças socioculturais: A agricultura quilombola no Vale do Ribeira-SP Brasil. Desenvolv. Meio Ambiente 2018, 49, 221-238. [CrossRef]

45. Hardin, G. The tragedy of the commons. J. Nat. Resour. Policy Res. 2009, 1, 243-253. [CrossRef]

46. Ostrom, E.E.; Dietz, T.E.; Dolšak, N.E.; Stern, P.C.; Stonich, S.E.; Weber, E.U. The Drama of the Commons; National Academy Press, APA PsycInfo: Washington, DC, USA, 2002.

47. Żelazna, A.; Bojar, M.; Bojar, E. Corporate Social Responsibility towards the Environment in Lublin Region, Poland: A Comparative Study of 2009 and 2019. Sustainability 2020, 12, 4463. [CrossRef]

48. Ulucak, R.; Ozcan, B. Relationship between energy consumption and environmental sustainability in OECD countries: The role of natural resources rents. Resour. Policy 2020, 69, 101803. [CrossRef]

49. Fang, Y.; Perc, M.; Xu, H. The Singaporean model in public goods dilemmas with benevolent leaders and bribery. J. Theor. Biol. 2020, 501, 110345. [CrossRef]

50. Ikhuoso, O.A.; Adegbeye, M.J.; Elghandour, M.M.Y.; Mellado, M.; Al-Dobaib, S.N.; Salem, A.Z.M. Climate change and Agriculture: The competition for limited resources amidst crop farmers-livestock herding conflict in Nigeria-A review. J. Clean. Prod. 2020, 272, 123104. [CrossRef]

51. Martinangeli, A.F.; Martinsson, P. We, the rich: Inequality, identity and cooperation. J. Econ. Behav. Organ. 2020, 178, 249-266. [CrossRef]

52. Alston, P.; Tomaševski, K. (Eds.) The Right to Food; Martinus Nijhoff Publishers: The Hague, The Netherlands, 1984; Volume 4.

53. Mechlem, K. Food Security and the Right to Food in the Discourse of the United Nations. Eur. Law J. 2004, 10, 631-648. [CrossRef]

54. Yue, S.; Munir, I.U.; Hyder, S.; Nassani, A.A.; Abro, M.M.Q.; Zaman, K. Sustainable food production, forest biodiversity and mineral pricing: Interconnected global issues. Resour. Policy 2020, 65, 101583. [CrossRef]

55. Green, A.; Nemecek, T.; Chaudhary, A.; Mathys, A. Assessing nutritional, health, and environmental sustainability dimensions of agri-food production. Glob. Food Secur. 2020, 26, 100406. [CrossRef]

56. Abusin, S.A.; Mandikiana, B.W. Towards sustainable food production systems in Qatar: Assessment of the viability of aquaponics. Glob. Food Secur. 2020, 25, 100349. [CrossRef]

57. García-Herrero, L.; Costello, C.; De Menna, F.; Schreiber, L.; Vittuari, M. Eating away at sustainability. Food consumption and waste patterns in a US school canteen. J. Clean. Prod. 2020, 279, 123571. [CrossRef]

58. Sigurdsson, V.; Larsen, N.M.; Alemu, M.H.; Gallogly, J.K.; Menon, R.V.; Fagerstrøm, A. Assisting sustainable food consumption: The effects of quality signals stemming from consumers and stores in online and physical grocery retailing. J. Bus. Res. 2020, 112, 458-471. [CrossRef] 
59. Saviolidis, N.M.; Olafsdottir, G.; Nicolau, M.; Samoggia, A.; Huber, E.; Brimont, L.; Fedato, C. Stakeholder Perceptions of Policy Tools in Support of Sustainable Food Consumption in Europe: Policy Implications. Sustainability 2020, 12, 7161. [CrossRef]

60. Amiri, A.; Mehrjerdi, Y.Z.; Jalalimanesh, A.; Sadegheih, A. Food System Sustainability Investigation using System Dynamics Approach. J. Clean. Prod. 2020, 277, 124040. [CrossRef]

61. Galli, F.; Prosperi, P.; Favilli, E.; D’Amico, S.; Bartolini, F.; Brunori, G. How can policy processes remove barriers to sustainable food systems in Europe? Contributing to a policy framework for agri-food transitions. Food Policy 2020, 96, 101871. [CrossRef]

62. Sarkar, D.; Kar, S.K.; Chattopadhyay, A.; Rakshit, A.; Tripathi, V.K.; Dubey, P.K.; Abhilash, P.C. Low input sustainable agriculture: A viable climate-smart option for boosting food production in a warming world. Ecol. Indic. 2020, 115, 106412. [CrossRef]

63. Patel, A.; Hrůzová, K.; Rova, U.; Christakopoulos, P.; Matsakas, L. Sustainable biorefinery concept for biofuel production through holistic volarization of food waste. Bioresour. Technol. 2019, 294, 122247. [CrossRef]

64. Ojha, S.; Bußler, S.; Schlüter, O.K. Food waste valorisation and circular economy concepts in insect production and processing. Waste Manag. 2020, 118, 600-609. [CrossRef] [PubMed]

65. Karandish, F.; Hoekstra, A.Y.; Hogeboom, R.J. Reducing food waste and changing cropping patterns to reduce water consumption and pollution in cereal production in Iran. J. Hydrol. 2020, 586, 124881. [CrossRef]

66. Fraser, E.D. The challenge of feeding a diverse and growing population. Physiol. Behav. 2020, 221, 112908. [CrossRef] [PubMed]

67. Feil, A.A.; da Silva Cyrne, C.C.; Sindelar, F.C.W.; Barden, J.E.; Dalmoro, M. Profiles of sustainable food consumption: Consumer behavior toward organic food in southern region of Brazil. J. Clean. Prod. 2020, 258, 120690. [CrossRef]

68. Annunziata, A.; Agovino, M.; Mariani, A. Sustainability of Italian families' food practices: Mediterranean diet adherence combined with organic and local food consumption. J. Clean. Prod. 2019, 206, 86-96. [CrossRef]

69. Graça, J.; Godinho, C.A.; Truninger, M. Reducing meat consumption and following plant-based diets: Current evidence and future directions to inform integrated transitions. Trends Food Sci. Technol. 2019, 91, 380-390. [CrossRef]

70. Reinders, M.J.; van Lieshout, L.; Pot, G.K.; Neufingerl, N.; van den Broek, E.; Battjes-Fries, M.; Heijnen, J. Portioning meat and vegetables in four different out of home settings: A win-win for guests, chefs and the planet. Appetite 2020, 147, 104539. [CrossRef]

71. McBey, D.; Watts, D.; Johnstone, A.M. Nudging, formulating new products, and the lifecourse: A qualitative assessment of the viability of three methods for reducing Scottish meat consumption for health, ethical, and environmental reasons. Appetite 2019, 142, 104349. [CrossRef]

72. Bonnet, C.; Bouamra-Mechemache, Z.; Réquillart, V.; Treich, N. Regulating meat consumption to improve health, the environment and animal welfare. Food Policy 2020, 101847. [CrossRef]

73. Sahakian, M.; Godin, L.; Courtin, I. Promoting 'pro','low', and 'no'meat consumption in Switzerland: The role of emotions in practices. Appetite 2020, 150, 104637. [CrossRef]

74. Elhoushy, S. Consumers' sustainable food choices: Antecedents and motivational imbalance. Int. J. Hosp. Manag. 2020, 89, 102554. [CrossRef]

75. Wegener, J. Equipping future generations of registered dietitian nutritionists and public health nutritionists: A commentary on education and training needs to promote sustainable food systems and practices in the 21st century. J. Acad. Nutr. Diet. 2018, 118, 393-398. [CrossRef] [PubMed]

76. Rose, D.; Heller, M.C.; Roberto, C.A. Position of the Society for Nutrition Education and Behavior: The importance of including environmental sustainability in dietary guidance. J. Nutr. Educ. Behav. 2019, 51, 3-15. [CrossRef] [PubMed]

77. Nyenhuis, J. A Quantitative Study on the Impact of Informal Culinary Nutrition Education on Societal Relationships, Connectedness and Food Choices in Rural Home Kitchens in Seven States. J. Acad. Nutr. Diet. 2019, 119, A140. [CrossRef]

78. The European Food Information Council (EUFIC). The Factors That Influence Our Food Choices. 2006. Available online: https://www.eufic.org/en/healthy-living/article/the-determinants-of-food-choice (accessed on 15 September 2020).

79. Leng, G.; Adan, R.A.; Belot, M.; Brunstrom, J.M.; de Graaf, K.; Dickson, S.L.; Reisch, L.A. The determinants of food choice. Proc. Nutr. Soc. 2017, 76, 316-327. [CrossRef] 
80. Veling, H.; Chen, Z.; Tombrock, M.C.; Verpaalen, I.A.; Schmitz, L.I.; Dijksterhuis, A.; Holland, R.W. Training impulsive choices for healthy and sustainable food. J. Exp. Psychol. Appl. 2017, 23, 204. [CrossRef]

81. Vermeir, I.; Verbeke, W. Sustainable food consumption among young adults in Belgium: Theory of planned behaviour and the role of confidence and values. Ecol. Econ. 2008, 64, 542-553. [CrossRef]

82. Larson, N.; Laska, M.N.; Neumark-Sztainer, D. Do young adults value sustainable diet practices? Continuity in values from adolescence to adulthood and linkages to dietary behavior. Public Health Nutr. 2019, 22, 2598. [CrossRef]

83. Grasso, A.C.; Hung, Y.; Olthof, M.R.; Verbeke, W.; Brouwer, I.A. Older consumers' readiness to accept alternative, more sustainable protein sources in the European Union. Nutrients 2019, 11, 1904. [CrossRef]

84. Ahmad Sirfan, A.S.; Hamirudin, A.H.; Sidek, S. Assessment of fruit and vegetable consumption among female university students. Food Res. 2020, 4, 1451-1460. [CrossRef]

85. Papies, E.K.; Johannes, N.; Daneva, T.; Semyte, G.; Kauhanen, L.-L. Using consumption and reward simulations to increase the appeal of plant-based foods. Appetite 2020, 155, 104812. [CrossRef] [PubMed]

86. Sharma, A.; Sonwaney, V. Theoretical modeling of influence of children on family purchase decision making. Procedia Soc. Behav. Sci. 2014, 133, 38-46. [CrossRef]

87. Mora, M.; Romeo-Arroyo, E.; Torán-Pereg, P.; Chaya, C.; Vázquez-Araújo, L. Sustainable and health claims vs sensory properties: Consumers' opinions and choices using a vegetable dip as example product. Food Res. Int. 2020, 137, 109521. [CrossRef] [PubMed]

88. Ivanova, D.; Stadler, K.; Steen-Olsen, K.; Wood, R.; Vita, G.; Tukker, A.; Hertwich, E.G. Environmental impact assessment of household consumption. J. Ind. Ecol. 2016, 20, 526-536. [CrossRef]

89. Dubois, G.; Sovacool, B.; Aall, C.; Nilsson, M.; Barbier, C.; Herrmann, A.; Dorner, F. It starts at home? Climate policies targeting household consumption and behavioral decisions are key to low-carbon futures. Energy Res. Soc. Sci. 2019, 52, 144-158. [CrossRef]

90. Wood, S.L.R.; Alam, M.; Dupras, J. Multiple pathways to more sustainable diets: Shifts in diet composition, caloric intake and food waste. Front. Sustain. Food Syst. 2019, 3, 89. [CrossRef]

91. Vermeir, I.; Weijters, B.; De Houwer, J.; Geuens, M.; Slabbinck, H.; Spruyt, A.; Verbeke, W. Environmentally sustainable food consumption: A review and research agenda from a goal-directed perspective. Front. Psychol. 2020, 11, 1603. [CrossRef]

92. Seo, Y.; Someya, Y.; Dowaki, K. Environmental impacts and consumer preference for sustainably cultivated Japanese mustard spinach, komatsuna. J. Environ. Manag. 2019, 231, 364-369. [CrossRef]

93. Clark, M.A.; Springmann, M.; Hill, J.; Tilman, D. Multiple health and environmental impacts of foods. Proc. Natl. Acad. Sci. USA 2019, 116, 23357-23362. [CrossRef]

94. Gracia, A.; Sánchez, A.M.; Jurado, F.; Mallor, C. Making Use of Sustainable Local Plant Genetic Resources: Would Consumers Support the Recovery of a Traditional Purple Carrot? Sustainability 2020, 12, 6549. [CrossRef]

95. Baur, P. When farmers are pulled in too many directions: Comparing institutional drivers of food safety and environmental sustainability in California agriculture. Agric. Hum. Values 2020, 37, 1-20. [CrossRef]

96. Pocol, C.B.; Marinescu, V.; Amuza, A.; Cadar, R.L.; Rodideal, A.A. Sustainable vs. Unsustainable Food Consumption Behaviour: A Study among Students from Romania, Bulgaria, and Moldova. Sustainability 2020, 12, 4699. [CrossRef]

97. Piester, H.E.; DeRieux, C.M.; Tucker, J.; Buttrick, N.R.; Galloway, J.N.; Wilson, T.D. “I'll try the veggie burger": Increasing purchases of sustainable foods with information about sustainability and taste. Appetite 2020, 155, 104842. [CrossRef] [PubMed]

98. Food and Agriculture Organization. Food-Based Dietary Guidelines. 2020. Available online: http://www.fao. org/nutrition/education/food-dietary-guidelines/regions/asia-pacific/en/ (accessed on 18 September 2020).

99. Verain, M.C.; Dagevos, H.; Antonides, G. Sustainable food consumption. Product choice or curtailment? Appetite 2015, 91, 375-384. [CrossRef]

100. Coşkun, A.; Özbük, R.M.Y. What influences consumer food waste behavior in restaurants? An application of the extended theory of planned behavior. Waste Manag. 2020, 117, 170-178. [CrossRef] [PubMed]

101. Marina, M.; Asma', A.; Jaafar, S.N.A.; Abdul Wahab, M.R.; Wan Zainal Shukri, W.H. Nutrition menu labelling in Terengganu: A cross-sectional study of knowledge, attitudes, perception and their relationship with healthy food choices. Food Res. 2020, 4, 1573-1581. [CrossRef] 
102. Cappelli, L.; D'ascenzo, F.; Ruggieri, R.; Rossetti, F.; Scalingi, A. The attitude of consumers towards “Made in Italy" products. An empirical analysis among Italian customers. Management \& Marketing. Chall. Knowl. Soc. 2019, 14, 31-47.

103. Everitt, B.S.; Skrondal, A. The Cambridge Dictionary of Statistics; Cambridge University Press: Cambridge, UK, 2010.

104. Yamane, T. Statistics: An Introduction Analysis; Harper \& Row: NewYork, NY, USA, 1973.

105. Sirigunna, J. Food safety in Thailand: A comparison between inbound senior and non-senior tourists. Procedia Soc. Behav. Sci. 2015, 197, 2115-2119. [CrossRef]

106. Oluwafemi, I.; Oluwafemi, J.; Laseinde, T.O.; Awoyemi, B.O.; Babatunde, A. Datasheet showing the impact of work environment on productivity in higher education institutions. Data Brief 2019, 25, 104090. [CrossRef]

107. Flurry, L.A.; Burns, A.C. Children's influence in purchase decisions: A social power theory approach. J. Bus. Res. 2005, 58, 593-601. [CrossRef]

108. Fisher, M.J.; Marshall, A.P. Understanding descriptive statistics. Aust. Crit. Care 2009, 22, 93-97. [CrossRef] [PubMed]

109. National Institute of Statistics of Romania. Population Structure b Gender. 2020. Available online: http: //statistici.insse.ro:8077/tempo-online/\#/pages/tables/insse-table (accessed on 25 September 2020).

110. Herbst, K.; Becker, G.M.A.; Harper, L.; Bagley, D.; Nieuwhof-Leppink, A.J.; Kaefer, M.; Kalfa, N. Don't be mean, be above average: Understanding data distribution and descriptive statistics. J. Pediatric Urol. 2020, 16, 712. [CrossRef] [PubMed]

111. Maric, M.; de Haan, E.; Hogendoorn, S.M.; Wolters, L.H.; Huizenga, H.M. Evaluating statistical and clinical significance of intervention effects in single-case experimental designs: An SPSS method to analyze univariate data. Behav. Ther. 2015, 46, 230-241. [CrossRef] [PubMed]

112. Lee, J.; Allen, J. Gender Differences in Healthy and Unhealthy Food Consumption and Its Relationship with Depression in Young Adulthood. Community Ment. Health J. 2020, 1-12. [CrossRef]

113. Graziani, A.R.; Guidetti, M.; Cavazza, N. Food for Boys and Food for Girls: Do Preschool Children Hold Gender Stereotypes about Food? Sex Roles 2020, 1-12. [CrossRef]

114. Trademap. Imports of vegetables in Romania. 2020. Available online: https://www.trademap.org/tradestat/ Country_SelCountry_MQ_TS.aspx?nvpm=1\%7c642\%7c\%7c\%7c\%7c07\%7c\%7c\%7c2\%7c1\%7c1\%7c1\%7c2\% 7c3\%7c2\%7c1\%7c1\%7c1 (accessed on 14 October 2020).

115. Church, A.; Mitchell, R.; Ravenscroft, N.; Stapleton, L.M. 'Growing your own': A multi-level modelling approach to understanding personal food growing trends and motivations in Europe. Ecol. Econ. 2015, 110, 71-80. [CrossRef]

116. Wong, J. Grow (just a bit of) your own. New Sci. 2020, 246, 22. [CrossRef]

Publisher's Note: MDPI stays neutral with regard to jurisdictional claims in published maps and institutional affiliations.

(C) 2020 by the authors. Licensee MDPI, Basel, Switzerland. This article is an open access article distributed under the terms and conditions of the Creative Commons Attribution (CC BY) license (http://creativecommons.org/licenses/by/4.0/). 